\title{
Application of Technological Changes in the Insurance Industry in India
}

\author{
Pratibha Maurya \\ Assistant Professor Grade-III, Amity University, Lucknow Campus, Lucknow \\ 2/123, Vikalp Khand Phase II, Gomti Nagar, Lucknow
}

\begin{abstract}
Digital India - the dream project of the government and a blessing for the citizens,could help in connecting the dots of various projects, past and present, to bring India to a global platform. It will help in moving with the universal trends of digital innovation and create positive impact in the lives of people - rural and urban, young and old. Insurance companies today are on the brink of big technology-driven changes and insurers need to rethink their customer engagement model. In this paper we have discussed about the importance of digitalization on the growth of the economies, the digitalization process in India and a study of the Insurance Industry since independence and the future of a digital insurer in the Indian context.
\end{abstract}

Keywords: Insurance, Digitalization, Organizations, Economy

\section{INTRODUCTION}

Digital technology is the important source of economic growth for national economies. It helps the economies in the creation of new jobs, improves the lives of the people and helps in building a better society. The individuals of a country, organizations, institutions and governments are making the more and more use of the digitalization program. It is changing life of the people, their working in the organization, their shopping habits, and their socialization and so on. It has brought drastic changes in the traditional industries and has brought a huge make over in the business environment from fashion industry to automobile industry, from logistics to transport to energy distribution. The technological development helps in gearing up and improving the way new innovative products and services are considered, manufactured and accessed. Digitalization is assisting business in the rapid development of the products and bringing them in the market which would have not been possible earlier.

\section{DIGITALIZATION IN INDIA}

Digitalization of the Indian economy is one of the important trust areas of work of the present government. It is going to be a blessing for the citizens of the country as it will connect them to the various projects and schemes of the government of India, various state governments and bring the country to a global platform. The digital India program will help in following with the global trends of digital revolution; create the favorable impact on the lives of the citizens of India whether they are young and old, rural or urban. As per the report of the World Bank, if there is an increase of $10 \%$ in the broadband and mobile users it results in the per capita GDP by $1.38 \%$ and $0.81 \%$ in the developing countries. If the Digital India project will be capable of increasing the mobile penetration in rural India from its current $45 \%$ by $30 \%$ in next two years and the broadband penetration across India from current $7 \%$, by $50 \%$, it would result into an increase in the GDP by $9 \%$ or $\$ 180$ billion (Deloitte). This would be the benefit of just 2 out of 9 focus areas of the Digital India project.

The advantages of the Digital India program of the Government of India are beyond imagination and the prospects to innovate in the digital world for the participant are restricted only by their own thoughts. The Aadhar card scheme was one of the major initiatives of the UPA government with the unique Identification Number would facilitate lifelong and distinctive identification and validation of citizens of India. This distinctive ID with the digital platform will help in the effective and justifiable delivery of the services at anytime, anywhere and on any device.

The increasing number of mobile users has become the best choice for achieving the inclusiveness in the various sectors like healthcare, financial, education and so on. The Government of India's Jan Dhan Yojna has resulted into opening of the 115 million new banks accounts in a period of less than one year. This was the first step of the government for financial inclusion in implementing the digitalization process. Many industries have followed the digitalization program of the government gradually and have started providing the content in the local language which would help in fulfilling the gap of urban and rural division. The digital business models help in getting a wider audience, make the services more inexpensive, attractive and feasible for the end users. The new 
business ventures like SuperProfs for online education, BigBasket for grocery at home, for home healthcare Portea Medical etc. are providing high quality services to the common people at low cost. E-Commerce is making a paradigm shift in delivering of sale and service and is replacing the traditional business models of having a store. As per the estimates of GSMA, the global business impact of connected life would be $\$ 3.4$ trillion by 2020 (Insurance 2020). India is going to be a big beneficiary of this. All these digital initiatives, technologies and services will have a multiplier effect of the Indian economy and will transform the governments, organizations, individuals, and society towards greater prosperity.

\section{INSURANCE INDUSTRY 3.1 Insurance Industry after Independence}

The life insurance business was nationalized on $19^{\text {th }}$ January, 1956. The Government of India brought together life insurers under one nationalized monopoly corporation and Life Insurance Corporation of India was born. At that time, there were 154 life insurance companies, 16 non-Indian companies and 75 provident societies were doing the life insurance business in India. Most of these companies were located in the metropolitan cities ie Bombay, Calcutta, Delhi and Madras. The general insurance business was not nationalized with the life insurance business. The then finance minister C.D. Deshmukh in his budget speech of 1956 said that, "II would also like to explain briefly why we decided not to bring in general insurance into the public sector (Speech of Shri Deshmukh, Minister of Finance, Budget 195657. The consideration which influenced us most is the basic fact that general insurance is a part and parcel of the private sector of trade and industry and functions on a year to year basis. Errors and omissions in the conduct of its business do not directly affect the individual citizen. Life insurance business, by contrast, directly concerns the individual citizen whose savings, so vitally needed for economic development, may be affected by any acts of folly or misfeasance on the part of those in control or be retarded by their lack of imaginative policy".

After sixteen years in 1972 the government nationalized the non-life insurance business (with effect from 1st January 1973). During that time there were 107 general insurance companies. These companies were usually large city-oriented, functioning at different levels of sophistication. When the nationalization was done these businesses were assigned to the four subsidiaries of the General Insurance Corporation of India (GIC). The General Insurance Business (Nationalization) Act 1972 provided that the
Government of India shall form a Government company as per the provisions of the companies Act 1956, to be known as General Insurance Corporation of India for the purpose of superintending, controlling and carrying on the business of general insurance (FICCI -BCG Insurance Report 2016).

\subsection{Beginning of Insurance Sector Reforms}

In the year, 1993 Government of India formed a Malhotra Committee to evaluate the performance of the Indian insurance industry and recommend its future directions. The committee was headed by the former Finance Secretary and the Governor of Reserve Bank of India Mr. R.N.Malhotra (Melhotra Committee Purpose and Recommendation). This committee suggested that the General Insurance Corporations should cease to be the holding company and focus on reinsurance business only. The four subsidiary companies were made independent companies. In the year 1994 the report was submitted by the committee, which recommended that the structure of the government companies should be changed and should be given more freedom in its operations. The private companies should be allowed to enter the industry. The foreign companies should also be permitted to enter the industry in collaboration with the domestic companies. The operations of the insurance industry should be computerized and technology updating should be carried out.

\subsection{Impact of reforms}

The insurance sector reforms brought a revolution in the Indian insurance industry. The monopoly of the government insurance companies was broken and the private players were allowed to enter the industry and do the insurance business. The Insurance Regulatory and Development Authority was formed to regulate and look after the affairs of the insurance business in India.

Since then there has been a consistent growth in the private insurance companies and their business. The number of insurers were 5 in the year 2000 which has increased to 50 today. With the passage of time, the life insurance penetration increased from 1.5 percent in 2000 to 2.6 percent in the financial year 2015, whereas the non-life insurance business has increased from 0.5 percent to 0.7 percent over the same years (IRDA). Over the years, there has been substantial change in the product portfolio as well as channel mix.

\subsection{Digital Insurance in India}

The insurance business is a personalized business where products are sold, on personal basis. The industry has been slow in the adoption of technology. Many leading insurance companies 
have started their journey towards digitalization. They have created the strategic teams to push the digital agenda at the enterprise level. In many companies, the CMO and their team unit has taken the initiative of the digitalization, while some have created new divisions in the organisations to push this agenda. The digitalization of an enterprise will help in achieving business and operational excellence. It is also useful to follow a systematic approach to transition from a traditional to a digital enterprise. The USER (Unify, Simplify, Engage, Respond) approach is the most appropriate guide for the companies in the transformation journey of the digitalization. The insurers can break down the initiative into smaller projects which can provide incremental business value than waiting for a complete long term program. The approach reestablished the focus on technology enablement and the adoption of naval technologies which can result into the optimization of operations, increasing the efficiency and the development of new products and new business models (Vinod Kachroo).

\subsubsection{Unify:}

Insurance companies usually operates as a storage tower for every line of the business, which results in the lack of data sharing through both product lines and channels and a high degree of unpredictability in customer experience. In the digitalization process, the most important requirement is to bring consistency across brands, products and channels and remove the tag of storage tower in the organization. The customers should be provided flexibility to select the product and switch between the channels. If a customer ends a transaction that was started in the mobile device, an agent should be able to take the lead and contact the customer to complete the sale. If a customer wants any help while completing a selfservice transaction, it may be able to make a call to the contact center and the service representative may help or complete the transaction where the customer has left. The companies can use social CRM which can help in identifying the social ambassadors who can promote their brands by making the use of word to mouth. The Bid Data can play a major role in this by enabling the merger of organised and unorganized data from inside and outside the organization, run analytics and gather customer specific insights.

\subsubsection{Simplify:}

The attaining of operational excellence is important for the sustenance of any company. This also applies with the insurance companies. This can be attained by following the process of business simplification. The Insurers should reassess their operations and make them simple for the new digital era. The measures like establishing unified processes across the brands, providing of the services through the mobile devices and making a single customer identity across the organization will both provide and demand opportunities for simplification. The digitalization of all paper-based transactions will not only result in cost saving for the organization but also increase efficiency through workflow digitalization. The simplification initiatives can be followed by reducing the various steps in the business process, merging the various processes into a single process, and decrease in the average time involved in the completion of the process. For the success of this initiative, there should be strong managerial backing, describing measurable results to enumerate the success of the initiative. The tasks of the business, IT and operations teams should be more than the process of simplification. Usually the insurance companies are hampered by the proliferation of distinct underlying IT systems acquired unsystematically over time without retiring older ones, or through mergers and acquisitions. The IT portfolio simplification is a large program in itself, it is the responsibility of the group owning the digital initiatives within the organization to ensure that they set this up as a critical reliance and manage the risks correctly.

\subsubsection{Engage:}

There is a tough competition in the insurance industry, reaching, engaging and holding customers and independent agents are crucial focus areas. The customer expects that insurer should understand their requirement and provide the services accordingly. Improving the tackiness of the customer and agents by using advanced engagement models will be a critical success factor in the shift from a traditional insurance company to a digital insurance organization. Insurers should invest profoundly in enabling such engagement through contextualized, collaborative solutions, integrated with the rest of the enterprise IT systems to provide superior customer and agent experiences. The companies should provide the right value added tools like financial calculators and commission planners to the consumers and agents. The insurance companies should not rely only on the old calculators made available on their website, as the consumers' expectations have changed with the technological innovations.

\subsubsection{Respond:}

The insurers, digital platform should be as per the needs of the users. Now a days users expect that the information should be available to them within the fraction of seconds and they can complete the insurance transactions from anywhere 
and at any time in the most convenient manner. In the new business environment, insurers must accept an enterprise integration strategy that connects multiple points to enable information exchange and provide a seamless customer experience. Real-time systems integration will help insurers use core application services and data to improve responsiveness to customer requests initiated using different channels. Such integration will also ensure a consistent channel-independent experience by making timely and accurate data available and accessible. Data will be available irrespective of whether a user initiates a transaction or communicates using a mobile phone or web browser, or via a call center representative or an agent.

Multi-channel analytics will also play a key role in building a responsive digital platform. Marketing campaign often show indications of being successful in one geography, or more effective through one distribution channel (say social media and not TV ads) and not another. In a digital enterprise, the insurer will be able to obtain this insight not after the campaign is over, but while it is going on, so that funding can be diverted to realize better yields.

\section{CONCLUSION}

The Digital India project provides a huge opportunity to use the latest technology to redefine the paradigms of service delivery. A digitally connected India can help in improving social and economic condition of people living in rural areas through development of non-agricultural economic activities apart from providing access to education, health and financial services like insurance and banking. According to analysts, the Digital India plan could boost GDP up to \$1 trillion by 2025 .

\section{REFERENCES}

[1] Deloitte, The fusion of business and IT: an Insurance Industry Perspective, Tech Trends

2015,https://www2.deloitte.com/.../Deloitt e/us/.../us-fsi-tech-trends-insurance-

perspective.pd...

[2] Damian Ryan \& Calvin Jones, understanding digital marketing, marketing strategies for engaging the digital generation, Kogan Page Limited, 2009.

[3] http://www.moneycontrol.com/digitizingi ndia/news/the-making-of-digital-india1399699.html.

[4] https://www.irdai.gov.in/

[5] https://www.google.co.in/search?q=\%E2 $\% 80 \%$ A2\%09Insurance-at-Digital-20x2020-Mar-2014-India_tcm21-
$28795++\&$ oq $=\%$ E2\%80\%A2\%09Insuranc e-at-Digital-20x-2020-Mar-2014-

India_tcm21-28795

[6] Hebbar K.C \& Shenoy S. Sandeep, The Role of Information Technology \& Insurance Penetration: A study, IRJBM, volume VII, October 14, Issue 10.

[7] Insurance 2020: Turning change into opportunity, www.pwc.com/insurance.

[8] Indiabudget.nic.in/bspeech/bs195657.pdf

[9] http://www.gr8ambitionz.com/2014/08/ma lhotra-committee-purposerecommendations.html

[10] Policy brief on the future of workAutomation and Independent work in a Digital Economy, OECD 2016.

[11] shodhganga.inflibnet.ac.in/bitstream/1060 3/20380/8/08_chapter\%202.pdf

[12] The changing face of Indian Insurance: In pursuit of profitable and sustainable growth, FICCI -BCG -Insurance Report 2016.

[13] Vinod Kachroo, Digital Transformation of the Insurance Industry -Driving Efficiency, Effectiveness and Growth, TATA Consultancy services,

[14] www.cii.in/PublicationDetail.aspx enc $=\mathrm{G}$ 6sU9YMPP0Y+O6/8akuSJrbk. 